Article

\title{
Indigenous Slaughter Techniques: Effects on Meat Physico-Chemical Characteristics of Nguni Goats
}

\author{
Zwelethu Mfanafuthi Mdletshe ${ }^{1,2}$, Michael Chimonyo ${ }^{1, *}$ and Cletos Mapiye ${ }^{3}$ \\ 1 Animal and Poultry Science, School of Agricultural, Earth and Environmental Sciences, University of \\ KwaZulu-Natal, Private Bag X01, Pietermaritzburg 3209, South Africa; zwelethu.mdletshe@ul.ac.za \\ 2 Department of Agricultural Economics and Animal Production, Faculty of Science and Agriculture, \\ University of Limpopo, Private Bag X1106, Sovenga 0727, South Africa \\ 3 Department of Animal Sciences, Faculty of AgriSciences, Stellenbosch University, Private Bag X1, \\ Matieland 7602, South Africa; cmapiye@sun.ac.za \\ * Correspondence: chimonyo@ukzn.ac.za; Tel.: +27-33-260-5477
}

check for updates

Citation: Mdletshe, Z.M.; Chimonyo, M.; Mapiye, C. Indigenous Slaughter Techniques: Effects on Meat Physico-Chemical Characteristics of Nguni Goats. Animals 2021, 11, 858. https://doi.org/10.3390/ani11030858

Received: 20 November 2020

Accepted: 8 January 2021

Published: 18 March 2021

Publisher's Note: MDPI stays neutral with regard to jurisdictional clai$\mathrm{ms}$ in published maps and institutional affiliations.

Copyright: $\odot 2021$ by the authors. Licensee MDPI, Basel, Switzerland. This article is an open access article distributed under the terms and conditions of the Creative Commons Attribution (CC BY) license (https:// creativecommons.org/licenses/by/ $4.0 /)$.
Simple Summary: In smallholder communal farming systems, Nguni people slaughter goats using indigenous methods which have cultural and spiritual significance to them. Nguni wethers were slaughtered using the transverse neck incision (TNI), suprasternal notch (SNP) and under the shoulder blade at the chest floor point of elbow piercing (CFP) to the direction of the heart to assess meat physico-chemical characteristics parameters. Nguni wethers slaughtered with the TNI and CFP methods produced meat with an acceptable appearance similar to goats slaughtered with the conventional standard procedures.

Abstract: To improve goat meat quality in rural communities, it is important to evaluate the effects of indigenous slaughter methods used by resource-limited farmers when performing traditional ceremonies on the meat physico-chemical characteristics. The current study assessed the effects of the meat physico-chemical characteristics of Nguni goats slaughtered with the transverse neck incision (TNI), suprasternal notch piercing (SNP) and the under shoulder blade piercing at the chest floor point of elbow (CFP) to the direction of the heart methods. Thirty Nguni weathers were randomly assigned to three slaughter treatments (10 goats/treatment). Musculus longissimus thoracis et lumborum (LTL) was sampled at post-mortem for physico-chemical characteristic measurements. Meat from wethers slaughtered with the SNP method had greater ultimate $\mathrm{pH}$ values than meat from wethers slaughtered with TNI and CFP slaughter methods. Wethers slaughtered with the SNP method had lower meat redness $\left(a^{*}\right)$, yellowness $\left(b^{*}\right)$, and chroma $\left(C^{*}\right)$ values than those slaughtered with TNI and CFP slaughter methods. Goat slaughter method did not affect meat drip loss, water holding capacity, cooking loss and shear force. Overall, Nguni wethers slaughtered with the TNI and CFP methods produced chevon with fresher meat appearance than those slaughtered using the SNP method.

Keywords: indigenous slaughter method; Nguni; chest floor piercing; suprasternal notch piercing; transverse neck incision; ultimate meat $\mathrm{pH}$

\section{Introduction}

Meat is an essential source of nutrients for most people [1]. In developing countries (e.g., Africa and the Middle East) where more than $90 \%$ of the world's goat population is found [2], goats are the second most important and abundant ruminant livestock species following cattle [3]. Such importance is due to their ability to graze and browse poor quality forage, survive feed- and water-scarce [4]. Furthermore, goats have high flock efficiency making them a short term investment [5]. Goats are owned and kept by smallholder farmers for meat (chevon), milk, manure, skin and hides [6]. Although smallholder farmers keep goats for socio-economic purposes, the primary reason is to use them for religious and cultural beliefs [7]. 
In 2018, FAOSTAT [2] estimated the world's total goat population at $1 \times 10^{9}$, with $40 \%$ of the population found in Africa. Southern Africa contribute $\%$ of Africa's goat population and $50 \%$ of that are found in South Africa [8]. Half of South Africas' smallholder households own goats, and more than $95 \%$ of goats are sold in the informal market for religious and cultural purposes [9]. When performing cultural practices, resource-limited households slaughter goats using indigenous methods [10,11], which have cultural meaning to them. The welfare of animals at commercial slaughterhouses is governed by the South African Meat Safety Act of 2000, which promotes stunning before exsanguination to ensure that animals are unconscious and experience minimal pain and suffering [11]. However, the Act accepts indigenous slaughter methods when done for personal use and cultural purposes. Indigenous slaughter methods include the transverse neck incision (TNI), suprasternal notch piercing (SNP) and the under shoulder blade piercing at the chest floor point of elbow (CFP) to the direction of the heart [12]. Cultural beliefs invoked when slaughtering goats using indigenous methods include celebrating circumcision, marriages and births, venerating ancestors, avenging evil spirits, and performing a ritual during funerals $[13,14]$. Immediately after slaughter and dressing, in most cases, the carcass is hanged with a metal hock in an empty room for $24 \mathrm{~h}$ for them to cool slowly, tenderize, dry and allow maximum blood loss. Such is important to resource-limited farmers because consuming meat with blood is prohibited, as it is believed that ancestral spirits do not accept meat with blood [13]. Offals are cleaned and consumed on the day of slaughter as they are highly perishable. Although indigenous slaughter methods have cultural meaning, therefore, approved by the Meat Safety Act of 2000, they affect the welfare and the meat physicochemical characteristics of goats.

Several studies published the effects of slaughter methods on meat physico-chemical characteristics focused on conventional methods, halal and kosher [15-17], and less, if any, on indigenous slaughter techniques used by resource-limited rural households in developing countries. While studies evaluating the effects of slaughter without stunning on meat physico-chemical characteristics are available $[16,17]$, there is a general perception that such slaughter methods have negative effects on meat quality since unconsciousness is not induced before bleeding. Understanding the effects of indigenous slaughter methods on physico-chemical attributes of goat meat will assist policymakers in developing costeffective, humane and culturally appropriate animal slaughter regulations. Therefore, the objective of the current study was to assess the effect of TNI, SNP and CFP methods on physico-chemical characteristics of Nguni goat meat.

\section{Materials and Methods}

\subsection{Compliance with Ethical Clearance}

The Animal Ethics Committee of the University of KwaZulu-Natal (AREC/001/018D) approved the experiment following the University guide which is compliant with the South African National Standards (SANS 10386:2008) for the care and use of animals in research and teaching.

\subsection{Goats and Experimental Design}

Thirty clinically healthy Nguni wethers with an average age of 16 months old and the bodyweight of $16.8 \pm 1.05 \mathrm{~kg}$ were purchased from the local rural farmers of Nongoma $\left(27^{\circ} 53^{\prime} \mathrm{S}, 31^{\circ} 38^{\prime} \mathrm{E}\right)$ in KwaZulu-Natal Province, South Africa. Resource-limited farmers managed goats in communal rangelands dominated by Vachellia karroo browse species. Goats were herded during the day and housed at night. Classification of goats as Nguni breed was based on the multiple coat colour patterns, small and compact frame size $[18,19]$. Goats were held in lairage for $16 \mathrm{~h}$ before slaughter with full access to water but without feed. At slaughter, goats were assigned to three (TNI, SNP and CFP) slaughter treatments (10 goats/treatment) in a completely randomized design. The slaughter process began at 05:00 a.m. and ended at 09:00 a.m. in the morning. 


\subsection{Treatments}

Slaughter of goats followed the Meat Safety Act (2000) regulations of South Africa. Wethers in the three slaughter treatments ( $n=10$ /treatment) were subjected to; transverse neck incision (TNI), under the shoulder blade at the chest floor point of elbow (CFP; Figure 1A) and suprasternal notch piercing with a short spear (SNP; Figure 1B). A sharp knife or a short spear designed explicitly for the slaughtering of goats was used. Slaughter of goats for the TNI was performed with a sharp knife. The knife severed the skin, muscles (brachiocephalic, sternocephalic, sternohyoid, and sternothyroid), trachea, oesophagus, carotid arteries, jugular veins and the major, superficial and deep nerves of the cervical region as described by Kiran [20]. Each cut was a change in the direction of movement of the knife. The SNP slaughter process was performed by two experienced slaughtermen using a short spear (Figure 1B). During slaughter, each goat was allowed to stand upright with hind legs. One slaughter man held the left front leg and the head (using horns) while the second slaughter man held the right front leg and the spear. The second slaughter men pierced the goat with the spear in the suprasternal notch in the direction of the heart. For the CFP method, piercing slaughter process was performed by three slaughtermen using a short spear (Figure 1A). Two slaughter men held each goat with front legs, allowing it to stand upright with hind legs. The third slaughter men pierced the goat on the heart girth position, next to the chest floor and point elbow to the direction of the heart. Spears and knives used during the slaughter and dressing of carcasses were sanitized by submerging them in boiling water for 1s. Blood was collected in buckets during the bleeding process.

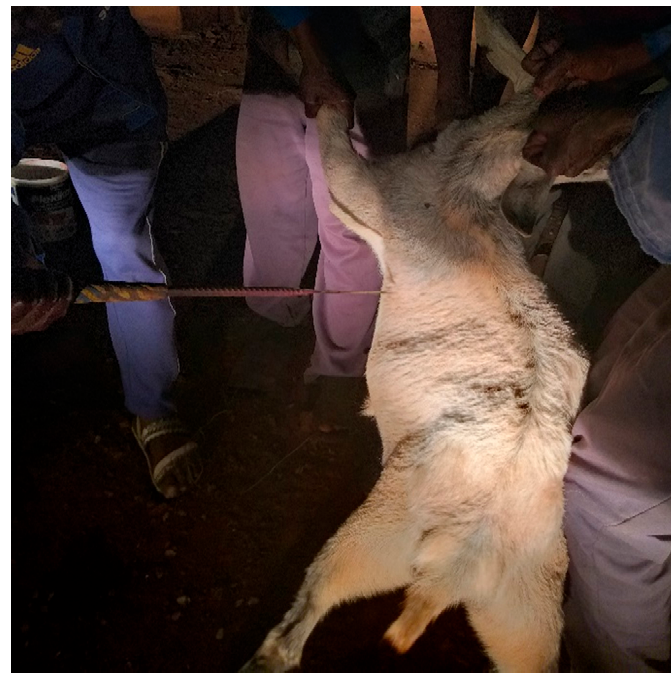

(A)

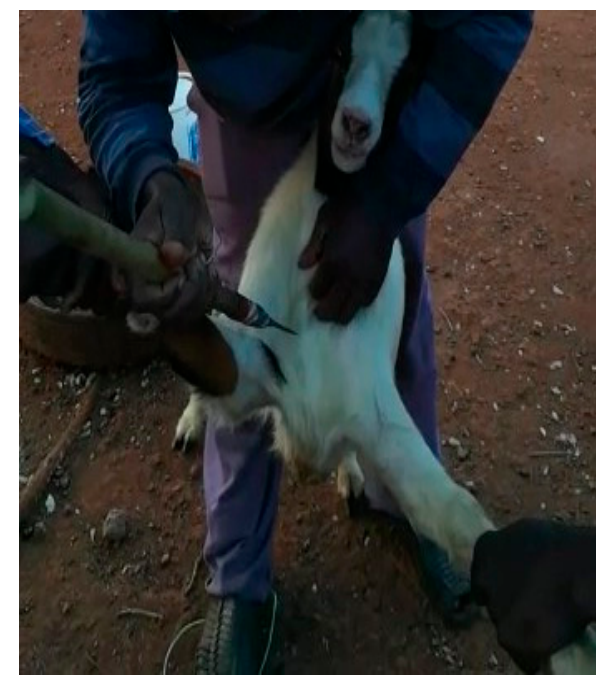

(B)

Figure 1. Visual pictures of the chest-floor point-of-elbow (A), and suprasternal notch piercing (B). Mdletshe et al. (2020), [12] with permission from MDPI.

\subsection{Meat Sampling and Storage}

The average dressed carcass weight was $8.60 \pm 0.90 \mathrm{~kg}$. The left and right longissimus thoracis et lumborum (LTL) were immediately removed between the 8th and 13th rib, immediately after dressing the carcass, vacuum-packed and placed in polystyrene cooler boxes $\left(<4{ }^{\circ} \mathrm{C}\right)$ and transported for $380 \mathrm{~km}$ to the Animal Science laboratory, at the University of KwaZulu-Natal, Pietermaritzburg, South Africa for physical and chemical analyses. On arrival at the laboratory after travelling for $8 \mathrm{~h}$, meat was stored at room temperature $\left(20^{\circ} \mathrm{C}\right)$ for $12 \mathrm{~h}$ pending analyses. 


\subsection{Measurements}

\subsubsection{Meat $\mathrm{pH}$}

Meat $\mathrm{pH}$ was measured $45 \mathrm{~min}$ and 24-h post-mortem using a portable $\mathrm{pH}$ meter probe (CRISON pH25, CRISON instrument SA, Barcelona, Spain).

\subsubsection{Meat Colour}

Meat colour was measured in triplicate $24 \mathrm{~h}$ after slaughter using a colour meter (HunterLab, ColorFlex EZ Spectrophotometer, Reston, VA, USA). The parameters used to evaluate meat colour followed colour CIE (1976) coordinates which measured: lightness $\left(L^{*}\right)$, redness $\left(a^{*}\right)$ and yellowness $\left(b^{*}\right)$ from three locations on the cut surface of individual meat samples. The Hue angle $\left(H^{*}\right)$ and chroma $\left(C^{*}\right)$ values were computed as follows:

$$
H^{*}=\tan ^{-1}\left(\frac{b^{*}}{a^{*}}\right) ; C^{*}=\left(\sqrt{a^{* 2}+b^{* 2}}\right) .
$$

\subsubsection{Drip Loss and Water Holding Capacity}

Drip loss was determined by suspending a standardized (40-50 $\mathrm{g}$ and approximately $30 \times 60 \times 25 \mathrm{~mm}$ ) sample of meat in an inflated transparent plastic bag and placed in a refrigerator for $48 \mathrm{~h}$ at $4{ }^{\circ} \mathrm{C}$ [21-23]. Percentage drip loss was calculated by dividing weight loss by initial weight and multiplying by 100 .

Water holding capacity (WHC) was determined by compressing approximately $3-4 \mathrm{~g}$ of meat with $30 \mathrm{~kg}$ of weight for $5 \mathrm{~min}$ using a texture analyser (Stable Micro System, Model TA.XT 2i/25, Godalming, UK). The water content of meat was determined by multiplying the initial weight of meat with 0.7 since the water content is $70 \%$ [24]. Water loss was determined by subtracting final weight from the initial value. Percentage water holding capacity was calculated by subtracting water loss from water content, dividing by water content and multiplying by 100 .

\subsubsection{Cooking Loss and Shear Force}

Fresh LTL samples were cut and weighed (initial weight) to form individual standardized slices of approximately $50 \mathrm{~mm}$ thick [25]. Meat samples were placed in a RATIONAL Granite-enamelled container $20 \mathrm{~mm}$ deep. A RATIONAL SCC 61E self-cooking centre (Landsberg, Munich, Germany) was used to roast LTL samples. The hot plate was preheated for $5 \mathrm{~min}$ to $205^{\circ} \mathrm{C}$ [26]. Immediately after preheating, a RATIONAL Granite-enamelled container $20 \mathrm{~mm}$ deep was placed onto a RATIONAL Grid; stainless steel 1/1GN were meat was roasted for $4 \mathrm{~min}$. After completing the cooking process, meat samples were cooled at room temperature and weighed. Percentage cooking loss was calculated as [(Initial weight of the sample - the weight of cooked sample) $\div$ initial weight of meat sample $\times 100]$.

Following cooking, sub-samples of specified core diameter parallel to the grain of the meat were used to determine WBSF (Warner-Bratzler Shear Force). Samples were sheared perpendicular to the fibre direction using a texture analyser model TA.XTplus, texture analyser (Stable Micro System, Model TA.XT 2i/25, UK). The mean maximum load recorded for the three cores were represented as the average of peak force in Newton's $(\mathrm{N})$ for each sample.

\subsection{Statistical Analyses}

All data were analysed using statistical analysis software (SAS) [27]. Normality of residuals tests for physico-chemical characteristics was computed using the UNIVARIATE procedure to assess data distribution. A general linear model procedure was used to test the effects of indigenous slaughter method on meat quality parameters.

The following model was used:

$$
Y_{i j}=\mu+S_{i}+\varepsilon_{i j}
$$


where

$Y_{i j k}=$ Response variables $\left(\mathrm{pH}, a^{*}, b^{*}, L^{*}, H^{*}, C^{*}\right.$, drip loss, water holding capacity, cooking loss, and shear force; dressing percentage);

$\mu=$ population mean;

$S_{i}=$ effect of indigenous slaughter method;

$\varepsilon_{i}=$ residual error.

The significance threshold for differences between least square means was set at $p \leq 0.05$.

\section{Results}

Ultimate $\mathrm{pH}_{24} \mathrm{~h}$, redness $\left(a^{*}\right)$, yellowness $\left(b^{*}\right)$ and chroma $\left(C^{*}\right)$ was not normally distributed $(p \leq 0.05)$. Initial live weight, dressed weight and dressing percentage were not different comparing slaughter treatments (Table 1). Slaughter method had no significant influence on pH 45 min (Table 1). Slaughter method had a significant effect on the ultimate $\mathrm{pH}_{24} \mathrm{~h}$. It was greater for the SNP when compared with the TNI and CFP slaughter methods (Table 1).

Table 1. Effects of indigenous slaughter methods on physico-chemical attributes of goat meat.

\begin{tabular}{|c|c|c|c|c|}
\hline \multirow{2}{*}{ Variable } & \multicolumn{3}{|c|}{ Slaughter Method } & \multirow{2}{*}{ Significance } \\
\hline & TNI & SNP & CFP & \\
\hline Intial weight & $17.3 \pm 0.31$ & $16.5 \pm 0.42$ & $16.1 \pm 0.38$ & NS \\
\hline Dressed weight & $8.44 \pm 0.31$ & $8.80 \pm 0.42$ & $8.67 \pm 0.38$ & NS \\
\hline $\mathrm{pH}_{45} \min$ & $7.79 \pm 0.10$ & $7.69 \pm 0.10$ & $7.58 \pm 0.10$ & NS \\
\hline $\mathrm{pH}_{24 \mathrm{~h}}$ & $6.40 \pm 0.13^{b}$ & $6.82 \pm 0.13^{\mathrm{a}}$ & $6.42 \pm 0.13^{b}$ & $*$ \\
\hline Drip loss (\%) & $3.0 \pm 0.75$ & $1.75 \pm 0.87$ & $1.88 \pm 0.75$ & NS \\
\hline $\begin{array}{l}\text { Water holding capacity }(\%) \\
\text { Colour parameters }\end{array}$ & $74.2 \pm 1.28$ & $75.6 \pm 2.21$ & $72.9 \pm 1.57$ & NS \\
\hline$a^{*}$ & $16.4 \pm 0.56^{\mathrm{a}}$ & $14.7 \pm 0.56^{\mathrm{b}}$ & $16.3 \pm 0.56^{\mathrm{a}}$ & * \\
\hline$b^{*}$ & $13.5 \pm 0.61^{\mathrm{a}}$ & $11.5 \pm 0.61^{\mathrm{b}}$ & $13.2 \pm 0.61^{\mathrm{a}}$ & * \\
\hline$L^{*}$ & $29.5 \pm 1.02$ & $28.3 \pm 1.02$ & $30.6 \pm 1.02$ & NS \\
\hline$H^{*}$ & $0.69 \pm 0.01$ & $0.66 \pm 0.01$ & $0.68 \pm 0.01$ & NS \\
\hline$C^{*}$ & $21.2 \pm 0.78^{\mathrm{a}}$ & $18.7 \pm 0.78^{b}$ & $21.0 \pm 0.78^{\mathrm{a}}$ & $*$ \\
\hline Cooking loss (\%) & $22.7 \pm 2.3$ & $21.6 \pm 3.0$ & $19.4 \pm 2.6$ & NS \\
\hline Shear force $(\mathrm{N})$ & $9.52 \pm 0.72$ & $10.7 \pm 0.83$ & $10.6 \pm 0.72$ & NS \\
\hline Dressing (\%) & $48.8 \pm 1.74$ & $53.4 \pm 2.34$ & $53.9 \pm 2.13$ & NS \\
\hline
\end{tabular}

$\overline{\mathrm{a}, \mathrm{b}}$ Means in the same row with different superscripts are significantly different at ${ }^{*} p \leq 0.05$; NS: not significant; TNI: transverse neck incision; SNP: suprasternal notch piercing; CFP: chest floor piercing; $\mathrm{pH}_{45 \mathrm{~min}}: \mathrm{pH} 45 \mathrm{~min}$ post-mortem; $\mathrm{pH}_{24} \mathrm{~h}$ : ultimate $\mathrm{pH} ; L^{*}$ : lightness; $a^{*}$ : redness; $b^{*}$ : yellowness; $H^{*}$ : Hue; $C^{*}$ : chroma.

Slaughter method influenced meat redness $\left(a^{*}\right)$, yellowness $\left(b^{*}\right)$ and chroma (Table 1$)$ values of meat from goats slaughtered using SNP method were lower than those of meat from goats slaughtered using TNI and CFP methods (Table 1). Slaughter method had no significant influence on the lightness $\left(L^{*}\right)$ and hue $\left(H^{*}\right)$ coordinates (Table 1). Similarly, no significant effect was observed for drip loss, WHC, cooking loss, shear force and dressing percentage.

\section{Discussion}

The high $\mathrm{pH}$ observed in meat from animals slaughtered using the SNP method is higher than Nguni goats slaughtered without stunning using the conventional methods $[28,29]$. This suggests these animals were more stressed than those slaughtered using other methods $[16,17]$. This could be explained by prolonged stress before and during slaughter, which may have led to a reduction in glycogen levels, and therefore low postmortem lactic acid production $[16,28,30]$. The causes of stress are, however, not immediately apparent. The prolonged stress could be related to nature, frequency, strength, severity, intensity, and duration of the stressor(s) before and during slaughter [12]. Such stressors 
include animal handling before and during slaughter and pain experienced by the animal during sticking and exsanguination [31]. These stressor(s) were not measured in the current study. Stress before and during slaughter can be measured by assessing cortisol and catecholamine concentration in urine [32]. Pain experienced by goats during sticking and exsanguination can be evaluated by comparing changes in electroencephalographic (EEG) activities with possible noxious stimuli [33]. Such merit further investigation.

The lower meat redness $\left(a^{*}\right)$ observed for the SNP slaughter treatment could have been influenced by prolonged stress before slaughter, resulting in the depletion of muscle glycogen, decreasing the amount of substrate available for anaerobic metabolism at the time of slaughter. Such limits post-mortem glycolysis, therefore resulting in high $\mathrm{pH}_{24} \mathrm{~h}$, which is a factor that promotes mitochondrial respiration and competition for oxygen in meat $[34,35]$. High $\mathrm{pH}_{24} \mathrm{~h}$ also results in low protein denaturation, which creates a more closed tissue structure. The closed structure reduces the diffusion of oxygen into the meat from the surface, and any oxygen that does not reach the interior is then utilized by high cytochrome activity which out-competes myoglobin for oxygen encouraged by high $\mathrm{pH}$ [36]. As a result, less oxymyoglobin is formed, and consequently, meat looks less red.

The observation that the SNP method had lower meat yellowness $\left(b^{*}\right)$ values than other methods could be explained by the effect of high meat $\mathrm{pH}_{24} \mathrm{~h}$ on oxygenation of the myoglobin [37-39]. The lower chroma $\left(C^{*}\right.$, colour intensity) values observed for the SNP slaughter method compared to other methods also corresponds high $\mathrm{pH}_{24} \mathrm{~h}$ values, which negatively correlates with low oxymyoglobin content in meat [40,41]. Such is influenced by the interaction between histidine from and bound oxygen which repel iron atoms out of the plane of porphyrin, making oxymyoglobin less compact. It is a well-known phenomenon that a decrease in oxymyoglobin content in meat is accompanied by lower values of $a^{*}, b^{*}$ and $C^{*}[42,43]$.

The finding that slaughter method did not affect drip loss, WHC, cooking loss and shear force agree with earlier reports [17,44,45]. Overall, the high $\mathrm{pH}$ (6.4-6.8), WHC, and low drip loss, $a^{*}, b^{*}$, and chroma values reported across slaughter methods are a characteristic of a dark firm and dry (DFD) meat [46,47]. This implies that all the goats across treatments had prolonged stress before and/or during slaughter and that could be related to the high temperamental behaviour of the Nguni goat breed among other stress factors [48]. Further studies to determine the pre-, peri- and post-mortem glycogen reserves, lactic acid concentration in muscles and stress hormones in Nguni goats could be necessary for explaining the effect of their temperamental behaviour on meat quality. Causes of pre- and perimortem stress that could be significant in minimising DFD meat from Nguni goats also merit investigation.

\section{Conclusions}

Nguni goats slaughtered using SNP slaughter method had higher $\mathrm{pH}_{24 \mathrm{~h}}$ than other slaughter methods, which resulted in lower meat redness, yellowness and chroma values. It was concluded that Nguni goats slaughtered using TNI and CFP methods may produce chevon with better meat colour than those slaughtered with the SNP method. The high meat $\mathrm{pH}_{24} \mathrm{~h}, \mathrm{WHC}$, and low drip loss and colour $\left(a^{*}, b^{*}\right.$, and chroma) indicate DFD meat. Further studies to determine the causes of DFD meat in Nguni goats slaughtered using indigenous methods are important.

Author Contributions: Formal analysis, Z.M.M.; Funding acquisition, M.C.; Methodology, Z.M.M.; Supervision, M.C.; Writing-original draft, Z.M.M.; Writing-review \& editing, C.M. All authors have read and agreed to the published version of the manuscript.

Funding: The authors thank the National Research, South Africa for funding the study (grant number: 99020). 
Institutional Review Board Statement: The study was conducted according to the University of KwaZulu-Natal University guide which is compliant with the South African National Standards (SANS 10386:2008) for the care and use of animals in research and teaching. The guidelines of the study were approved by the ethics committee of the University of KwaZulu-Natal (AREC/001/018D).

Informed Consent Statement: Not applicable for studies not involving humans.

Data Availability Statement: The data presented in this study is available on request from the corresponding author. The data is not publicly available because participants did not consent.

Acknowledgments: The authors thank the National Research Fund for funding the study. We also thank farmers, traditional leaders and extension officers for assisting with slaughtering goats.

Conflicts of Interest: The authors declare no conflict of interest. The funders had no role in the design of the study; in the collection, analyses, or interpretation of data; in the writing of the manuscript, or in the decision to publish the results.

\begin{tabular}{ll}
\multicolumn{2}{l}{ Abbreviations } \\
TNI & transverse neck incision \\
SNP & suprasternal notch piercing \\
CFP & under shoulder blade chest floor point of elbow piercing \\
LTL & muscle longissimus thoracis et lumborum \\
$a^{*}$ & Redness \\
$b^{*}$ & Yellowness \\
$C^{*}$ & chroma values \\
FAOSTAT & Food and Agriculture Organization Corporate Statistical \\
L & litre \\
WHC & Water holding capacity \\
GLM & general linear model \\
SAS & statistical analysis software \\
PDIFF & Requests that $p$-values for differences \\
DFD & dark: firm and dry
\end{tabular}

\section{References}

1. Webb, E.C.; O'Neill, H.A. The animal fat paradox and meat quality. Meat Sci. 2008, 80, 28-36. [CrossRef] [PubMed]

2. FAOSAT. Food and Agriculture Organization of the United Nations. Available online: http://www.fao.org/faostat/en/\#data/ QA2020 (accessed on 18 May 2020).

3. Mapiye, C.; Chimonyo, M.; Dzama, K.; Raats, J.G.; Mapekula, M. Opportunities for improving Nguni cattle production in the smallholder farming systems of South Africa. Livest. Sci. 2009, 124, 196-204. [CrossRef]

4. Mdletshe, Z.M.; Chimonyo, M.; Marufu, M.C.; Nsahlai, I.V. Effects of saline water consumptions on physiological responses in Nguni goats. Small Rumin Res. 2017, 153, 209-211. [CrossRef]

5. Lebbie, S.H.B. Goats under household conditions. Small Rumin Res. 2004, 51, 131-136. [CrossRef]

6. Rumosa Gwaze, F.; Chimonyo, M.; Dzama, K. Communal goat production in Southern Africa: A review. Trop. Anim. Health Prod. 2009, 41, 1157-1168. [CrossRef]

7. Mdletshe, Z.M.; Ndlela, S.Z.; Nsahlai, I.V.; Chimonyo, M. Farmer perceptions on factors influencing water scarcity for goats in resource-limited communal farming environments. Trop. Anim. Health Prod. 2018, 50, 1617-1623. [CrossRef] [PubMed]

8. Mohlatlole, R.P.; Dzomba, E.F.; Muchadeyi, F.C. Addressing production challenges in goat production systems of South Africa: The genomics approach. Small Rumin Res. 2015, 131, 43-49. [CrossRef]

9. National Agriculture Marketing Council. Report on the Investigation into the Potential for the South African Goat Industry. 2005. Available online: https:/ / www.nda.agric.za/docs/AAPS/NAMC1.pdf (accessed on 19 May 2020).

10. Msimang, C.T. Kusadliwa Ngoludala, 2nd ed.; Shuter \& Shooter (Pty) Ltd.: Pietermaritzburg, South Africa, 2007.

11. Qekwana, D.N.; Oguttu, J.W. Assessment of Food Safety Risks Associated with preslaughter activities during the traditional slaughter of goats in Gauteng, South Africa. J. Food Prot. 2014, 77, 1031-1037. [CrossRef]

12. Mdletshe, Z.M.; Marufu, M.C.; Chimonyo, M. Effect of Indigenous Slaughter Methods on the Behavioural Response, Bleeding Efficiency and Cardiac Arrest of Nguni Goats. Animals 2020, 10, 247. [CrossRef]

13. Ntuli, M.S. Ucwaningo Olunzulu Ngesiko Lokubuyisa Ithongo. Master's Thesis, University of Zululand, Empangeni, South Africa, 2004. 
14. Qekwana, D.N.; McCrindle, C.M.E.; Oguttu, J.W.; Grace, D. Assessment of the occupational health and food safety risks associated with the traditional slaughter and consumption of goats in Gauteng, South Africa. Int. J. Environ. Res. Public Health 2017, 14, 420. [CrossRef]

15. Velarde, A.; Gispert, M.; Diestre, A.; Manteca, X. Effect of electrical stunning on meat and carcass quality in lambs. Meat Sci. 2003, 63, 35-38. [CrossRef]

16. Sabow, A.B.; Sazili, A.Q.; Zulkifil, I.; Goh, Y.M.; AB Kadir, M.Z.A.; Adeyemi, K.D. Physico-chemical characteristics of Longissimus lumborum muscle in goats subjected to halal slaughter and anesthesia (halothane) pre-slaughter. Anim. Sci. J. 2015, 86, 981-991. [CrossRef] [PubMed]

17. Sabow, A.B.; Adeyemi, K.D.; Idrus, Z.; Meng, G.Y.; Kadir, M.Z.A.A.; Kaka, U.; Aghwan, Z.A.; Abubakar, A.A.; Sazili, A.Q. Carcase characteristics and meat quality assessments in goats subjected to slaughter without stunning and slaughter following different methods of electrical stunning. Ital. J. Anim. Sci. 2017, 16, 416-430. [CrossRef]

18. Snyman, M.A. South African Goat Breeds: Indigenous Veld Goat. Info-Pack Ref. 2014/004; Grootfontein Agricultural Development Institute: Great Karoo, South Africa, 2014.

19. Ncube, K.T.; Hadebe, K.; Dzomba, E.F.; Soma, P.; Frylinck, L.; Muchadeyi, F.C. Relationship between population genomic structure and growth profiles of South African goats under different production systems. Trop. Anim. Health Prod. 2020, 52, 1277-1286. [CrossRef] [PubMed]

20. Kiran, M.; Naveena, B.M.; Smrutirekha, M.; Baswa Reddy, P.; Rituparna, B.; Praveen Kumar, Y.; Venkatesh, C.; Rapole, S. Traditional halal slaughter without stunning versus slaughter with electrical stunning of sheep (Ovis aries). Meat Sci. 2019, 148, 127-136. [CrossRef] [PubMed]

21. Honikel, K.O. Reference Methods for the Assessment of Physical Characteristics of Meat. Meat Sci. 1998, 49, 447-457. [CrossRef]

22. Christensen, L.B. Drip loss sampling in porcine $m$. longissimus dorsi. Meat Sci. 2003, 63, 469-477. [CrossRef]

23. Tayengwa, T.; Chikwanha, O.C.; Dugan, M.E.R.; Mutsvangwa, T.; Mapiye, C. Influence of feeding fruit by-products as alternative dietary fibre sources to wheat bran on beef production and quality of Angus steer. Meat Sci. 2020, 161, 107969. [CrossRef]

24. Webb, E.C. Goat meat production, composition, and quality. Anim. Front. 2014, 4, 33-37. [CrossRef]

25. Purslow, P.P.; Oiseth, S.; Hughes, J.; Warner, R.D. The structural basis of cooking loss in beef: Variations with temperatures and ageing. Food Res. J. 2016, 89, 739-748. [CrossRef]

26. Cheng, J.; He, Z.; Qin, F.; Cheng, J.; Cao, D.; Guo, F.; Zeng, M. Inhibitory profiles of spices against free and protein-bound heterocyclic amines of roast beef patties as revealed by ultra-performance liquid chromatography-tandem mass spectrometry and principal component analysis. Food Funct. 2017. [CrossRef]

27. SAS. Statistical Analysis System Institute Inc. Users Guide, Version 9.4; SAS: Carry, NC, USA, 2010.

28. Simela, L.; Webb, E.C.; Frylinck, L. Effect of sex, age, and pre-slaughter conditioning on $\mathrm{pH}$, temperature, tenderness and colour of indigenous South African goats. S. Afr. J. Anim. Sci. 2004, 34, 208-211.

29. Xazela, N.M.; Chimonyo, M.; Muchenje, V.; Marume, U. Effects of sunflower cake supplementation on meat quality of indigenous goat genotypes of South Africa. Meat Sci. 2012, 90, 204-208. [CrossRef] [PubMed]

30. Kim, Y.H.B.; Warner, R.D.; Rosenvold, K. Influence of high pre-rigor temperature and fast $\mathrm{pH}$ fall on muscle proteins and meat quality: A review. Anim, Prod. Sci. 2014, 54, 375-395. [CrossRef]

31. Sabow, A.B.; Goh, Y.M.; Zulkifli, I.; Sazili, A.Q.; Ab Kadir, M.Z.A.; Kaka, U.; Khadijah, N.; Adeyemi, K.D.; Ebrahimi, M. Electroencephalographic responses to neck cut and exsanguination in minimally anaesthetized goats. S. Afr. J. Anim. Sci. 2017, 47, 34-40. [CrossRef]

32. Bozzo, G.; Barrasso, R.; Marchetti, P.; Roma, R.; Samoilis, G.; Tantillo, G.; Ceci, E. Analysis of Stress Indicators for Evaluation of Animal Welfare and Meat Quality in Traditional and Jewish Slaughtering. Animals 2018, 8, 43. [CrossRef]

33. Sabow, A.B.; Goh, Y.M.; Zulkifli, I.; Sazil, A.Q.; Kaka, U.; Ab Kadi, M.Z.A.; Ebrahimi, M.; Nakyinsige, K.D.; Adeyemi, K.D. Blood parameters and electroencephalographic responses of goats to slaughter without stunning. Meat Sci. 2016, 121, 148-155. [CrossRef]

34. McKeith, R.O.; King, D.A.; Grayson, A.L.; Shackelford, S.D.; Gehring, K.B.; Savell, J.W.; Wheeler, T.L. Mitochondrial abundance and efficiency contribute to lean color of dark cutting beef. Meat Sci. 2016, 116, 165-173. [CrossRef]

35. Zhang, Y.; Hopkins, D.L.; Zhao, X.; van de Ven, R.; Mao, Y.; Zhu, L.; Luo, X. Characterisation of pH decline and meat color development of beef carcasses during the early post-mortem period in a Chinese beef cattle abattoir. J. Integr. Agric. 2018, 17, 1691-1695. [CrossRef]

36. Warriss, P.D. Meat Science: An Introductory Text, 2nd ed.; CABI: Wallingford, UK, 2010.

37. Lindahl, G.; Lundström, K.; Tornberg, E. Contribution of pigment content, myoglobin forms and internal reflectance to the colour of pork loin and ham from pure breed pigs. Meat Sci. 2001, 59, 141-151. [CrossRef]

38. Karamucki, T.; Jakubowska, M.; Rybarczyk, A.; Gardzielewska, J. The influence of myoglobin on the colour of minced pork loin. Meat Sci. 2013, 94, 234-238. [CrossRef] [PubMed]

39. Hernández, B.; Sáenz, C.; Alberdi, C.; Diñeiro, J.M. CIELAB color coordinates versus relative proportions of myoglobin redox forms in the description of fresh meat appearance. Int. J. Food Sci. Technol. 2016, 53, 4159-4167. [CrossRef] [PubMed]

40. Abril, M.; Campo, M.M.; Önenç, A.; Sañudo, C.; Albertí, P.; Negueruela, A.I. Beef colour evolution as a function of ultimate pH. Meat Sci. 2001, 58, 69-78. [CrossRef] 
41. Li, X.; Zhang, D.; Ijaz, M.; Tian, G.; Chen, J.; Du, M. Colour characteristics of beef longissimus thoracis during early $72 \mathrm{~h}$ postmortem. Meat Sci. 2020, 170, 108245. [CrossRef] [PubMed]

42. Gašperlin, L.; Žlender, B.; Abram, V. Colour of norma land high pH beef heated to different temperatures as related to oxygenation. Meat Sci. 2000, 54, 391-398. [CrossRef]

43. Lindahl, G.; Karlsson, A.H.; Lundström, K.; Andersen, H.J. Significance of storage time on degree of blooming and colour stability of pork loin from different crossbreeds. Meat Sci. 2006, 72, 603-612. [CrossRef]

44. Vergara, H.; Linares, M.B.; Berruga, M.I.; Gallego, L. Meat quality in suckling lambs: Effect of pre-slaughter handling. Meat Sci. 2005, 69, 473-478. [CrossRef]

45. Agbeniga, B.; Webb, E.C.; O’Neil, H.A. Influence of Kosher (Shechita) and conventional slaughter techniques on shear force, drip and cooking loss of beef. S. Afr. J. Anim. Sci. 2013, 43, 98-102. [CrossRef]

46. Ponnampalam, E.N.; Hopkins, D.L.; Bruce, H.; Li, D.; Baldi, G.; Bekhit, A.E. Causes and Contributing Factors to "Dark Cutting" Meat: Current Trends and Future Directions: A Review. Compr. Rev. Food Sci. Food Saf. 2017, 16, 400-430. [CrossRef]

47. Frimpong, S.; Gebresenbet, G.; Bobobee, E.; Aklaku, E.D.; Hamdu, I. Effect of Transportation and Pre-Slaughter Handling on Welfare and Meat Quality of Cattle: Case Study of Kumasi Abattoir, Ghana. Vet. Sci. 2014, 1, 174-191. [CrossRef]

48. Ndou, S.P.; Muchenje, V.; Chimonyo, M. Behavioural responses of four goat genotypes to successive handling at the farm. Afr. J. Biotechnol. 2010, 9, 8118-8124. 